\title{
Causality Relationship between Foreign Direct Investment, Trade and Economic Growth in Pakistan
}

\author{
Muhammad Shahzad Iqbal (Corresponding author) \\ Lecturer, Department of Business Studies \\ The University of Faisalabad, Faisalabad, Pakistan \\ Tel: 92-300-866-0601_E-mail: shahzad.iqbaal@gmail.com
}

Faiz Muhammad Shaikh

Assistant Professor

SZABAC-Dokri

Larkana-Sindh-Pakistan

E-mail: faizmuhammed_2000@yahoo.com

Amir Hussain Shar

Assistant Professor

Department of Commerce Salu-Khairpur, Pakistan

\begin{abstract}
The research investigates the causality relationship between FDI, Trade Economic growth in Pakistan. Using quarterly time series data from 1998 to 2009, this paper examines the causality relationship between foreign direct investment, international trade and economic growth in Pakistan. In VAR model, the integration and Cointergration analysis suggested that there is a long run relationship among the factors. The results of VECM causality test find bidirectional causality between foreign direct investment, export and economic growth, with are two important factors that enhance the affect of economic growth in Pakistan. Foreign Direct Investment has positive impact on the trade growth in Pakistan. It was revealed that government should play a positive role in proving security to the investors around the globe. It was further revealed that FDI should invest in various parts of Baluchistan as well as rural part of Sindh province.
\end{abstract}

Keywords: Foreign direct investment, Trade, Economic growth, Granger causality and Pakistan

\section{Introduction}

Since the launch of market-oriented economic reforms in 2000, Pakistan has been among the fastest growing countries in the Southeast Asia with the active participation of foreign investors in all fields of the economy. The Pakistani government has quickly jointed competition for foreign direct investment into regional and global markets by restructuring of the domestic economy; and opening up of the economy to the external trade and investment to increase its economy. For some recent years, Pakistan's GDP growth rate is average 7.5\% annually, total trade in 2005 is 23.5 times compared to 1986 and the total registered capital of FDI in Pakistan in 2001-2005 is about 13 times of that in 1988-2000 periods. Even though Pakistan has showing the sign of increasing in all FDI, trade and economic growth, none of previous researches try to examine the causality relationship between those factors due to lack of data for analysis. This paper aims to investigate the causality relationship between foreign direct investment, international trade and economic growth in Pakistan by Vector Auto Regression (VAR) method. The next part summarizes the facts of FDI, trade and economic growth in Pakistan since its renovation in 1986. After reviewing some empirical literature about the relationship of FDI and trade and growth, the paper sets a model to test the FDI, trade and economic growth relationship. Then, the empirical results of Pakistan's case study could be presented in part V. Conclusions is in final part.

\section{FDI, trade and economic growth in Pakistan}

Pakistan has been in transition from a centrally planned to a market oriented economy since December 1996, from that time until now, Pakistan had seen remarkable economic achievements in growing gross domestic 
product (GDP), GDP per capita, foreign direct investment and important trade and economic agreements signed with major partners.

\subsection{Economic growth}

Pakistan's economic growth rates were dramatically increasing since 1986 (table 1). From a low economic growth rate of $2.8 \%$ in 1986, the annual growth rate of Pakistan has increased to $6 \%$ in 1988 and increased to over 9\% in both 1995 and 1996.The first decreased in the growth rate was in 1989 and 1990 due to the beginning collapse of the Socialism system of Soviet Union and Eastern Europe. From 4.4\% of average GDP growth rate in 1986-1990, it was increased dramatically up to $8.18 \%$ in 1991-1995. This resulted in increasing per capita income from $\$ 100$ in 1987 to over $\$ 300$ in 1996 (Ben, 1999). However, due to effectiveness of Asian financial crisis in 1997-1998, the GDP growth rates were declined to 5.8\% in 1998 and lowest rate at $4.8 \%$ in 1999 . The economy was successfully recovery after the crisis and developed at $7.48 \%$ of growth rate at the five-year plan 2001-2005. Overcoming several difficulties and challenges, with $8.4 \%$ of economic growth in 2005, Pakistan has finished the year of 2005 with highest growth rate during the first five years of the 21 century. This achievement and the stable develop of the society showed the chosen renovation of Pakistan leader going in the right goals, contents and implemented measures at macro level to ensure growth and overcome the crisis. Pakistan economy has been transformed towards increasing in the industry and service and decreasing in the agriculture, forestry and fishery since 1986. Table 1 shows that agriculture, forestry and fishing factor was accounted for $49 \%$ of total GDP output during 1981-1985, and it continuously decreased until 22.29\% in 2001-2005. Industry and services sectors are more important share in GDP by counting for $39.44 \%$ and $38.27 \%$ in the first half of the 21 century, increased nearly $12 \%$ share in industry and $15 \%$ share in services.

\subsection{FDI performance}

Since reforms were implemented in 1986, FDI has been seen as imperative to growing the Pakistan economy and plays an important role for Pakistan's economy. The growth of FDI in Pakistan is one of the most dramatic consequences of Pakistan's change in economic policy from a planned economy towards a market oriented economy. According to Pakistan Statistical Yearbook 2005, there are 7279 FDI projects received investment licenses with total registered capital amounting to US\$66244.4 million since 1988 up to December 2005 (figure 1). Even though the number of contracts in the five -year 2001-2005 are more than double of that in the five year 1996- 2000, the registered capital in 2001-2005 period are still smaller than that in1996-2000 period with amounted of US $\$ 5538.8$ million. The registered capital in 1996 was got the highest amount during the time (US\$10164.1 million) and accounted for 1/6 of total capital registered.

During FY04-06, Pakistan has cumulatively attracted $\$ 8$ billion foreign investment flows $-26.5 \%$ was sale proceeds of public assets and $49.2 \%$ from FDI, with remaining coming from foreign portfolio investment. These foreign inflows have come into banking, telecom and oil and gas sectors primarily. Prospects are that Pakistan will attract about US\$6.0 billion in FY07 - an all time high annual flow advent of deregulation, privatization, and liberalization policies initiated at the end of the 1980s. The amount of foreign investment rose from a tiny $\$ 10.7$ million in 1976/1977 to $\$ 1296$ million in 1995/1996, thus growing at the annual compound growth rate of 25.7 percent. However, it declined to $\$ 950$ million in 1996/1997. With overall liberalization program (1991/1992 onwards) the inflow of foreign investment grew at the compound growth rate of 15.2 percent. Investment inflows in 1995/1996 increased by $93.3 \%$ mainly due to the inflow of investment in power sector.

The investment has now risen to a figure of $\$ 3521$ million in 2005-06. This depicts a $332 \%$ increase from 2001-02 to 2006-07 in case of direct foreign investment. Although significant by absolute terms, the increase appears trivial when compared to the relatively more buoyant economies of East and Southeast Asia. While FDI flows to all developing countries reached $\$ 233.2$ billion in 2004, East and Southeast Asia received the bulk of this share, total foreign investment consists of direct and portfolio investment. The major component of the total foreign investment is FDI. Despite yearly fluctuations, the amount of FDI rose from \$484.7 million in 2001-02 to \$million in 2006-07. Since the beginning of the liberalization program, FDI has grown faster than in the pre-liberalization period (1984/1985-1990/1991). In particular, 1995/1996 registered a phenomenal growth of $146.5 \%$ mainly due to the inflow of FDI in the power sector. FDI, on average, accounted for more than $100 \%$ of total inflows over the period 2001-02 to 2006-07.

\subsection{International trade}

From 1990 to 2007, annual average growth rate of export is $21.22 \%$ per year. Export value in 2005 was 40.8 times of 1986 , from $\$ 0.79$ billion in 1986 to $\$ 32.23$ billion in 2005 . The share of exports in total trade increase steadily from $35.7 \%$ in the $1986-1990$ up to $46 \%$ in the $2001-2005$ periods. The annual average growth rate of imports in 1986-2005 is $16.1 \%$ per year. Import value over 2005 was only counted for 17.1 times that of the year 
1986 , increased from $\$ 2.16$ billion to $\$ 36.88$ billion USD. The average growth rate of imports in 1991-1995 is the highest (24.3\%), compared to other periods, although the import values only equals to $1 / 5$ of the one in 2001-2005 periods. The combination of export and import growth at different speeds has made the balance of trade more complicated. Trade deficits were nearly unchanged in 1986-1990 and 1991-1995 periods. This volume increases so quickly in the second half of the 1990s and in the first half of the 21 century. In 2001-2005, Pakistan trade deficit was almost double and fourfold compared to that of 1996-2000 and 1991-1995, respectively. However, the deficit ratio in each period compared to exports was strongly decreased, from $80.4 \%$ in $1986-1990$ to $17.4 \%$ in $2001-2005$. This was resulted by the increasing of export's growth rate each year so much larger than that of imports. The trade deficit situation can be explained as follows. Firstly, Pakistan was continuously increasing its economic growth rates over the past year, so that it was also increasing the demand for materials of production. Moreover, the imported material's prices were strongly increased in some recent years to force Pakistan's import values increasing. Lastly, to develop the trade liberalization with the world countries, Pakistan was and will become a supporter for the world imports.

\section{Model or vertical FDI}

They also predict that the complementary relationship is normally found for vertical FDI as in the models of Helpman (1984), Helpman and Krugman (1985) and Grossman and Helpman (1991). FDI substitutes trade when the investment is horizontal as in Horizontal FDI consists of the production of the same goods and services in different Locations Vertical FDI consist the geographical fragmentation of the production progress by stages in order to reduce costs 7th models of Markusen (1983), Horstmann and Makusen (1992), Brainard (1993), Makusen and Venables (1995) and Helpman, Melitz and Yeaple (2004). While the theoretical arguments support both complementary and substitutability effects, empirical works on this question almost show a net complementary relationship between trade and FDI. Even though studies were at firm level studies (as in the studies of Lipsey and Weiss (1984), Head and Ries (2001), Mucchielli et. al. (2000)), at industry level ( as Mankovska (2000), Pfaffermayr (1996) and Brainard (1997)), and at country level ( as in Grubert and Mutti (1999), Andersen \& Hainaut (1998), Clausing (2000), Teo and Wang (2001) and Mekki (2003)), those studies show the positive relationship of FDI and international trade. However, the results seem to be sensitive to the choice of explanatory variables, country, and the time period of different samples studying.

\section{Methodology of FDI, trade and economic growth's causality testing}

The objective of this paper is to recognize the directly causal relationship between FDI inflows, economic growth and trade (including export and import) in Pakistan based on a systematic approach. Granger's definition of causality is framed in terms of predictability. The basic principle of Granger-causality analysis (Granger, 1969) is to test whether or not lagged values of one variable help to improve the explanation of another variable from its own past. Considering two time series stationary variables Xt and Yt, according to Granger (1969), Yt is said to "Granger-cause" Xt ( $\mathrm{Y} \rightarrow \mathrm{X}$ ) if and only if lagged $\mathrm{Yt}$ 's help predict and improve Xt. Many tests of causality have been derived and implemented such as Granger (1969), Sims (1972) and Geweke et al. (1982) (see Hamilton (1994)). However, one of the most well- knowing methods to solve this matter is Vector Auto Regression (VAR). Extended from Granger causality analysis of Granger 91969), the VAR technique in econometric modeling was the first to introduce in the Econometrica Journal by Christopher A. Sims in 1980. To analyze the dynamic impact of random disturbances on the systems of variables, VAR methodology superficially resembles simultaneous-equation modeling (SEM) in that we consider several endogenous variables together. Each endogenous variable is explained by its lagged values and the lagged values of all other endogenous variables.

\section{Data}

The empirical analysis was presented by time series model. The time period of analysis is quarter time series data from 1988 to 2005 in Pakistan. Most of the data on variables used in the tests are taken and calculated from Pakistan's Statistical Yearbook of General Statistics Office, Pakistan. Since 11GDP is denominated in Pakistan and the FDI, import and export are in US dollars, the FDI, import and export data are converted into Pak-rupee using yearly average VNR/US dollar exchange rate obtained from the socio-economic data indicators in Pakistan -20 years of renovation and development, General Statistics Office, Pakistan. Then all data is converted to the based year data 1994 by using the GDP deflator $(1994=100)$ for better comparisons.

\subsection{Unit root tests}

We used the Augmented Dickey Fuller (ADF) test for testing the unit root in time series. Lag length of each variable is chosen by computer automatically based on minimum values of Schwartz Info Criterion (SIO) statistics and max lag is 11 . The test equations include constant. The results are presented in Table 3. The results 
shown in Table 3 suggest that the null hypothesis of a unit test in the time series can not be rejected on variable levels in a logarithm form. However, all of variables are stationary in their first differences Therefore, all the variables are integrated of order one, I(1).

\subsection{Cointergration test}

As presented in the last part, the important point of Vector Autoregressive model is the number of lag's order of variables. A chosen appropriate lag length of the variables could create the best model with uncorrelated and homoskedastic residuals. The optimal lag length can be selected from computed data as the minimum value of the Akaike Information Criterion (AIC) and Schwartz Bayesian Criterion (SBC) statistics. Table 4 suggested the lag order of 3 that yields the minimum Akaike's Final Prediction error (FPE), Schwartz Information Criteria (SIC), Hannan-Quinn information (HQ) and LR values.

As all variables are determined I(1), the Cointergration test is performed for the long run relationship among series by using Johansen cointegration test.

Table 5 presents the results of Johansen cointegration test with a cointegration rank of four and two in both the trade test and the maximum Eigen value test, thereby there are exiting the long run relationship among the variables.

\subsection{Granger causality test in Vector error correction mechanism model (VECM)}

Based on the results of unit root and Cointergration test, we will use vector error correction mechanism in a VAR model to recognize the direction of the variables. Causality inferences among pairs of variables in the multivariate VECM model are based upon estimating the parameters of the model, subject to the predetermined number of co integrating vectors in the 13 system, using the Johansen maximum likelihood method.

\section{The results presented in Table 5.}

As shown, the bidirectional causality between FDI and GDP, FDI and EXPORT, GDP and EXPORT, and IMPORT and EXPORT. There are only unidirectional between FDI AND IMPORT, and GDP and IMPORT. However, there are only unidirectional causal connection running from IMPORT to FDI and GDP. The results are consistent with growth theories that export promotion and attracting FDI can generate permanent effects on the level of GDP. It also consistent with the theories about determinant of FDI that economic growth and openness of a country are the important factors attracting FDI inflows. The results suggested that FDI invested in Pakistan was attracted by its economic growth and its foreign trade strategy. On the other hand, the results also illustrated that FDI and trade are two important factors that effect economic growth in Pakistan.

\section{Conclusion}

The purpose of this study is to examine the link between FDI, trade and economic growth in Pakistan. The paper first presents some stylized facts of patterns of FDI inflows, international trade and economic growth in Pakistan. This shows that both international trade and economic growth are increasing over time. FDI in Pakistan fluctuated in the 1990s, and then increased in the first half of 21 st century. Next, a three - step - empirical analysis of the causations between FDI, trade and economic growth is presented in quarterly data of Pakistan from 1988:1 to 2005:4. As those variables are integrated in I(1) and cointergrated, the VECM framework used to test the causality relationship between the variables. Paper show the two way causal connections exist between economic growth, export and FDI, with unidirectional of import to export and FDI. This could conclude that FDI invested in Pakistan was attracted by its economic growth and its foreign trade strategy. Moreover, FDI and trade are two important factors that enhance the affect of economic growth in Pakistan.

\section{References}

Athukorala, P., and H. Hill. (1999). Foreign Investment in East Asia: A Survey. Asian-Pacific Economic Literature, 12: 23-50.

Athukorala. P.C. and Jayasuriya, S. and Oczkowski, E. (1995). Multinational firms and export performance in developing countries: Some analytical issues and new empirical evidence. Journal of Development Economics, 46: 109-122.

Balasubramanyam, V.N., M.A. Salisu and D. Sapsford. (1996). Foreign Direct Investment and Growth in EP and IS Countries. Economic Journal, 106: 92-105.

Balasubramanyam, V.N., Salisu, M. and Sapsford, D. (1999). Foreign Direct Investment as an engine of growth. Journal of International Trade and Economic Development, 8, No.1: 27-40.

Bhat, K.S., Tripura Sundari C.U., and K.D. Raj. (2004). Causal Nexus between Foreign Direct Investment and 
Economic Growth in India. Indian Journal of Economics, 85: 171-185

Borensztein, E., J. De. Gregorio, and J-W. Lee. (1998). How does foreign direct investment affect growth? Journal of International Economics, 45: 111-135.

De Mello, L.R. and K. Fukasaku. (2000). Trade and foreign direct investment in Latin America and Southeast Asia: temporal causality analysis. Journal of International development, 12: 903-924, 15

Dritsaki, M. et all. (2004). A causal relationship between trade, foreign direct investment and economic growth for Greece. American Journal of applied sciences, 1(3): 230-235.

Granger, C.W.J. (1986). Developments in the Study of the Cointergrated Economic Variables. Oxford Bulletin of Economics and Statistics, 48: 201-212.

Granger, C.W.J. (1988). Some Recent Developments in a Concept of Causality. Journal of Econometrics, 39: 199-211.

Granger, C.W.J., and A. A. Weiss. (1983). Time Series Analysis of Error Correction Models', pp.255-278, in S. Karlin, T. Amemiya and L.A. Goodman (eds.), Studies in Econometrics: Time Series and Multivariate Statistics, New York (Academic Press): 255-278.

Granger, C.W.J., B.-N. Huang and C.-W. Yang. (2000). A Bivariate Causality between Stock Prices and Exchange Rates: Evidence from Recent Asian Flu. The Quarterly Review of Economics and Finance, 40: 337-354.

Granger, Clive W.J. (1969). Investigating Casual Relations by Econometric models and cross-spectral methods. Econometrica, 37: 424-438.

Grossman, Gene and Helpman, Elhannan. (1991). Innovation and Growth in the Global Economy. MIT Press, Cambridge.

Hsiao, F. and M. Hsiao. (2006). FDI, exports and GDP in East and Southeast Asia-Panel data versus time series causality analyses. Journal of Asian Economics, 17: 1082-1106.

Johansen S. (1988). Statistical analysis of Cointergration vectors. Journal of Economic Dynamics and Control, 12:231-54.

Johansen, S. and Jesulius, K. (1990). Maximum likelihood estimation and inference on Cointergration-with application to the demand for money. Oxford Bulletin of Economics and Statistics, 52: 169-210.

Johansen, S. and Jesulius, K. (1992). Testing Structural Hypothesis in a multivariate Cointergration analysis of the PPP and the UIP for UK. Journal of Econometrics, 53: 211-244.

Kojima, K. (1975). International trade and Foreign Investment: Substitutes or Complements. Hitotsubashi Journal of Economics, 16: 1-12.

Kojima, K.. (1973). A Macroeconomic Approach to Foreign Direct Investment. Hitotsubashi Journal of Economics, 14: 1-21.

Liu, X., P. Burridge and P. Sinclair. (2002). Relationship between economic growth, foreign direct investment and trade: evidence from China. Applied economics, 34: 1433-1440. 
Table 1. Foreign Direct Investment Inflow (Country wise)

\begin{tabular}{|l|c|c|c|c|c|c|c|c|c|}
\hline \multicolumn{1}{|c|}{ Country } & $2000-01$ & $\begin{array}{c}2001-0 \\
2\end{array}$ & $2002-03$ & $2003-04$ & $2004-05$ & $2005-06$ & $\begin{array}{c}\text { July-Jan. } \\
2007-08\end{array}$ & Total & $\%$ of Total \\
\hline USA & 92.7 & 326.4 & 211.5 & 238.4 & 326.0 & 516.7 & 512.9 & $4,293.8$ & 28.8 \\
U.K & 90.5 & 30.3 & 219.4 & 64.6 & 181.5 & 244.0 & 488.2 & $2,457.7$ & 16.5 \\
Japan & 9.1 & 6.4 & 14.1 & 15.1 & 45.2 & 57.0 & 34.3 & 522.4 & 3.5 \\
UAE & 5.2 & 21.5 & 119.7 & 134.6 & 367.5 & $1,424.5$ & 295.9 & $2,607.6$ & 17.5 \\
Germany & 15.5 & 11.2 & 3.7 & 7.0 & 13.1 & 28.6 & 21.6 & 306.7 & 2.1 \\
Korea & 3.7 & 0.4 & 0.2 & 1.0 & 1.4 & 1.6 & 1.0 & 201.3 & 1.3 \\
Saudi Arabia & 56.6 & 1.3 & 43.5 & 7.2 & 18.4 & 277.8 & 9.5 & 489.9 & 3.3 \\
France & 0.7 & -6.9 & 2.6 & -5.6 & -3.6 & 3.2 & -1.5 & 81.3 & 0.5 \\
Netherlands & 4.8 & -5.1 & 3.0 & 14.0 & 36.7 & 121.1 & 62.5 & 318.5 & 2.1 \\
Hong Kong & 3.6 & 2.8 & 5.6 & 6.3 & 32.3 & 24.0 & 26.2 & 168.1 & 1.1 \\
Italy & 1.3 & 0.1 & 0.2 & 1.9 & 0.4 & 0.0 & 0.0 & 17.7 & 0.1 \\
Canada & 0.1 & 3.5 & 0.5 & 0.5 & 1.9 & 4.8 & 1.6 & 24.1 & 0.2 \\
Other & 38.6 & 92.8 & 174.0 & 464.4 & 503.2 & 817.7 & 643.8 & $3,434.0$ & 23.0 \\
\hline Total & 322.4 & 484.7 & 798.0 & 949.4 & $1,524.0$ & $3,521.0$ & $2,096.0$ & $14,923.1$ & 100.0 \\
\hline
\end{tabular}

Source: ADB-Foreign Direct Investment Inflow (Country wise) from 2000-01 to January 2007

Table 2. Foreign Direct Investment in Different Sectors, Sector wise Distribution of FDI in Pakistan (2002-2006-07).

\begin{tabular}{|c|c|c|c|c|c|}
\hline & 2002-03 & 2003-04 & 2004-05 & 2005-06 & 2006-07 \\
\hline Country & $\%$ age & $\%$ age & $\%$ age & $\%$ age & $\%$ age \\
\hline U.S.A. & 26.51 & 25.1 & 21.4 & 14.7 & 24.5 \\
\hline U.K. & 27.49 & 6.8 & 11.9 & 6.9 & 23.3 \\
\hline U.A.E. & 15.00 & 14.2 & 24.1 & 40.5 & 14.1 \\
\hline Switzerland & - & 21.6 & 9.0 & 4.8 & 6.2 \\
\hline Netherlands & - & - & 2.4 & - & 3.0 \\
\hline Mauritius & - & - & - & - & 2.1 \\
\hline Saudi Arabia & 5.45 & - & - & 7.9 & - \\
\hline Norway & - & 15.4 & - & 7.2 & - \\
\hline Japan & 1.77 & 1.6 & 3.0 & - & - \\
\hline Others & 23.78 & 15.2 & 28.2 & 18 & 26.8 \\
\hline Total & 100 & 100 & 100 & 100 & 100.0 \\
\hline
\end{tabular}

Source: ADB-Annual reports2006- 2007

Table 3. ADF Unit root test

Null hypothesis: $\operatorname{lnFDI}, \operatorname{lnEX}$, lnIM and lnGDPC contain unit root

Variable

ADF Test statistic ( p value)

\begin{tabular}{lcc}
\hline & On $\mathbf{1}^{\text {st }}$ difference series & On level series \\
\hline $\ln \mathrm{FDI}$ & $-1.96(0.30)$ & $-4.85(0.00)^{* * *}$ \\
$\ln \mathrm{EX}$ & $-0.34(0.91)$ & $-5.86(0.00)^{* * *}$ \\
$\ln \mathrm{M}$ & $0.28(0.97)$ & $-8.03(0.00)^{* * *}$ \\
$\ln \mathrm{GDPC}$ & $1.25(0.99)$ & $-6.47(0.00)^{* * *}$
\end{tabular}

Note: (1) Test critical values at $1 \%, 5 \%$ and $10 \%$ level are $-3.53,-2.91$ and -2.59 , Respectively

(2) $* * *, * *$ and $*$ denote rejection of null hypothesis at $1 \%, 5 \%$ and $10 \%$ level of significance, respectively. 
Table 4. VAR Lag Order Selection Criteria

\begin{tabular}{|l|l|l|l|l|l|l|}
\hline Lag & Log L & LR & FPE & AIC & SC & HQ \\
\hline 0 & -73.65246 & -5.65246 & 0.0001 & 242.353105 & 2.4858 & 112.405543 \\
\hline 1 & 344.5202 & 772.9859 & $6.31 \mathrm{e}-10$ & -9.833947 & -9.17041 & -9.571754 \\
\hline 2 & 370.5407 & 44.94444 & $4.68 \mathrm{e}-10$ & -10.13760 & -8.943240 & -9.665650 \\
\hline 3 & 377.8022 & 11.66235 & $6.19 \mathrm{e}-10$ & -9.872793 & -8.147610 & -9.191091 \\
\hline 4 & 396.8769 & 28.32316 & $5.79 \mathrm{e}-10$ & -9.965968 & -7.709960 & -9.074512 \\
\hline 5 & $-12.19266^{*}$ & $-9.405827^{*}$ & $-11.09145^{*}$ & 486.3578 & $122.0193^{*}$ & $6.53 \mathrm{e}-11^{*}$ \\
\hline 6 & 500.7193 & 17.84312 & $7.34 \mathrm{e}-11$ & 12.14301 & -8.825351 & -10.83204 \\
\hline
\end{tabular}

* indicates lag order selected by the criterion

LR: sequential modified LR test statistic (each test at 5\% level)

FPE: Final prediction error

AIC: Akaike information criterion

SC: Schwarz information criterion

HQ: Hannan-Quinn information criterion

Table 5. Johansen cointegration test

Null hypothesis: lnFDI, lnEX, lnIM and lnGDPC are no cointegration, VAR

$\operatorname{lag}=5$

\begin{tabular}{|c|c|c|c|c|c|}
\hline Null & Alternative & $\begin{array}{l}\text { Trace } \\
\text { Statistics }\end{array}$ & $\begin{array}{l}95 \% \\
\text { Critical value }\end{array}$ & $\begin{array}{l}\text { Max-Eigen } \\
\text { Statistics }\end{array}$ & $\begin{array}{l}95 \% \\
\text { Critical value }\end{array}$ \\
\hline Rank $=0$ & $\mathrm{r} \geq 1$ & $61.7788 * * * *$ & 43.74 & $36.77 * * *$ & 26.78 \\
\hline Rank $\leq 1$ & $r \geq 2$ & $30.5667 * * *$ & 23.87 & 17.89 & 20.89 \\
\hline Rank $\leq 2$ & $r \geq 3$ & $11.234 * *$ & 13.67 & 11.34 & 13.56 \\
\hline Rank $\leq 3$ & $\mathrm{r} \geq 4$ & $3.30 *$ & 3.90 & $3.90 * *$ & 2.90 \\
\hline
\end{tabular}

Note (1) Test includes intercepts (not trend) and linear deterministic trend

(2) $* *$ and $* * *$ denote rejection of null hypothesis at the $5 \%$ and $1 \%$ level, respectively 
Table 6. VEC Granger Causality/Block Exogeneity Wald Tests, VAR lag $=5$

Null hypothesis: column variable does not cause the row variable

Note: $* * *, * *$ and $*$ denote rejection of null hypothesis at the $1 \%, 5 \%$ and $10 \%$ level of

Significance, respectively

Dependent variables

Chi square test statistics Causality directions

$\Delta \operatorname{lnFDI} \Delta \ln$ GDP $\Delta \ln E X P O R T \Delta \operatorname{lnIMPORT}$

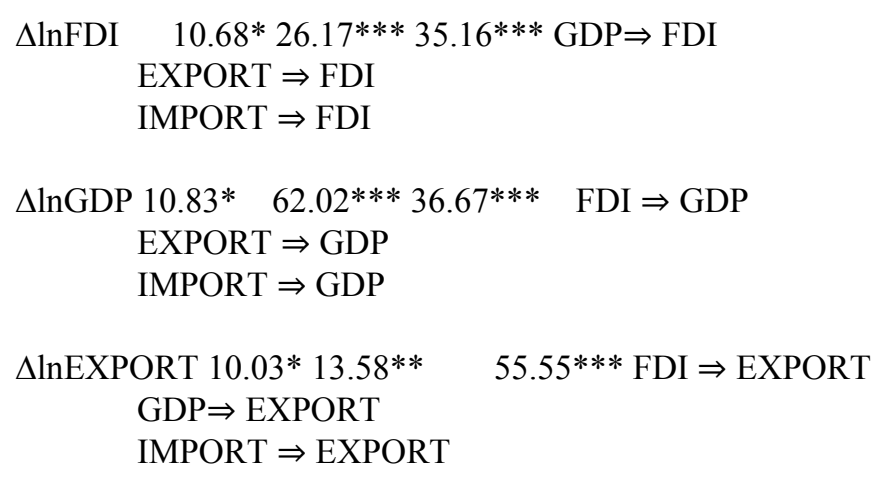

$\Delta \operatorname{lnIMPORT} 4.017 .949 .26^{*} \quad$ EXPORT $\Rightarrow$ IMPORT

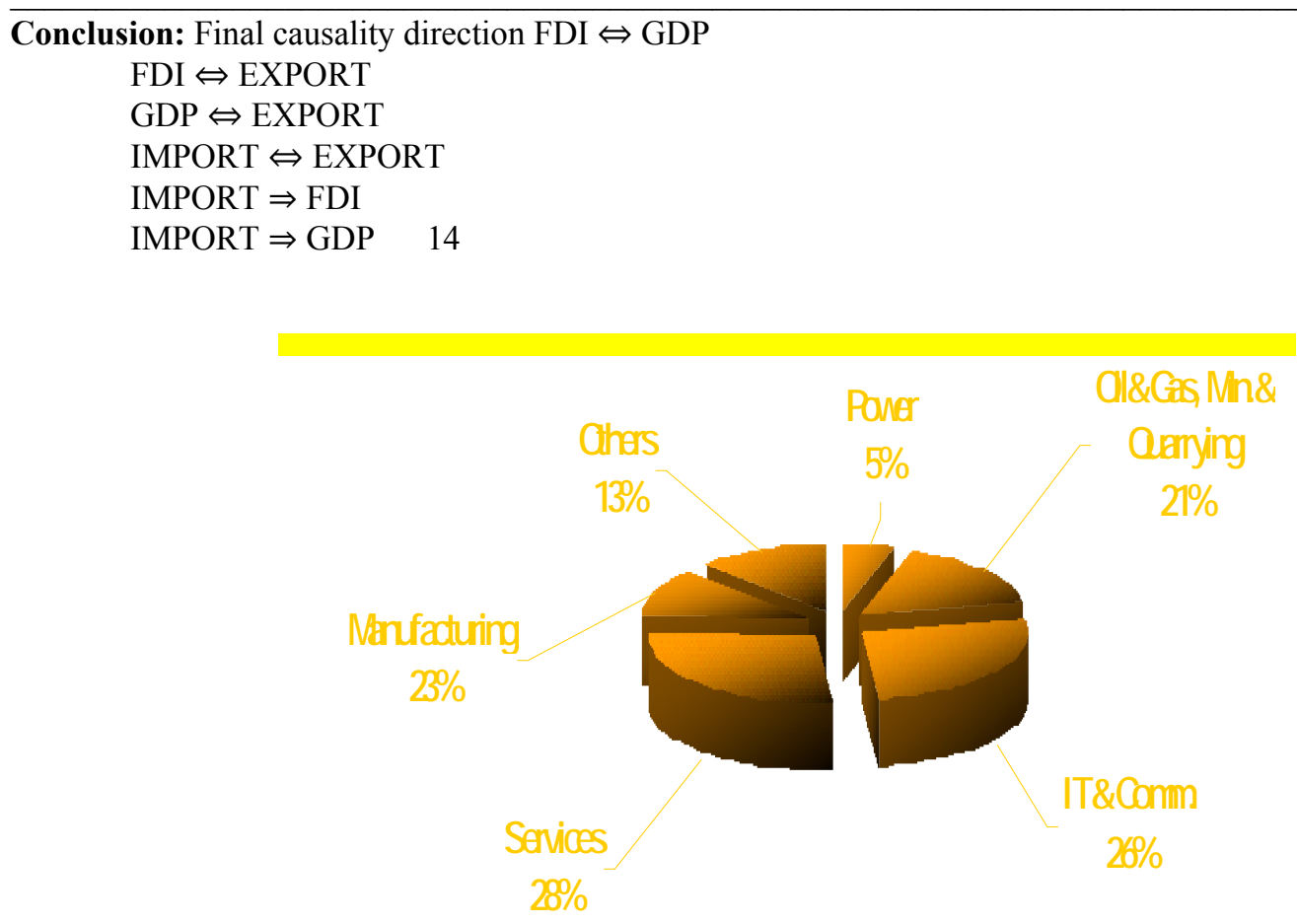

Source: Country-wise FDI: Sources of FDI (2000-2007)

Figure 1. Sector and Country-wise Analysis of FDI (2000-2007) 